\title{
Presence AND Re-Sighting of SoUthern elephant Seal, Mirounga leONINA (L. 1758), ON THE NORTH-CENTRAL COAST OF CHILE
}

\author{
Maritza Sepúlveda ${ }^{1,2,}$, María José Pérez-Alvarez ${ }^{1,2}$, Paula López ${ }^{1}$ \& Rodrigo Moraga ${ }^{1,2}$
}

Keywords: Mirounga leonina, southern elephant seal, phocids, Chile, re-sightings, molt

The southern elephant seal (Mirounga leonina) is a large predator in the higher levels of trophic webs, and one of the principal consumers of squid and fish in the southern marine ecosystem (Bradshaw et al., 2003; Hindell et al., 2003). The annual cycle of this species is characterized by two terrestrial phases: one for breeding (September to November) and one for molting (December to March); and two pelagic foraging phases: post-breeding (for about 2-3 months), and post-molt (lasting 7 months) (Campagna et al., 1993; 2000).

This species has a circumpolar distribution throughout the Southern Ocean with a total world population estimated of 664000 individuals (Laws, 1994), and major breeding areas close to the Antartic Polar Front (Laws, 1994; Lewis et al., 1998). The world population is divided into four distinct groups, namely the Kerguélen stock in the South Indian Ocean, the South Georgia stock in the

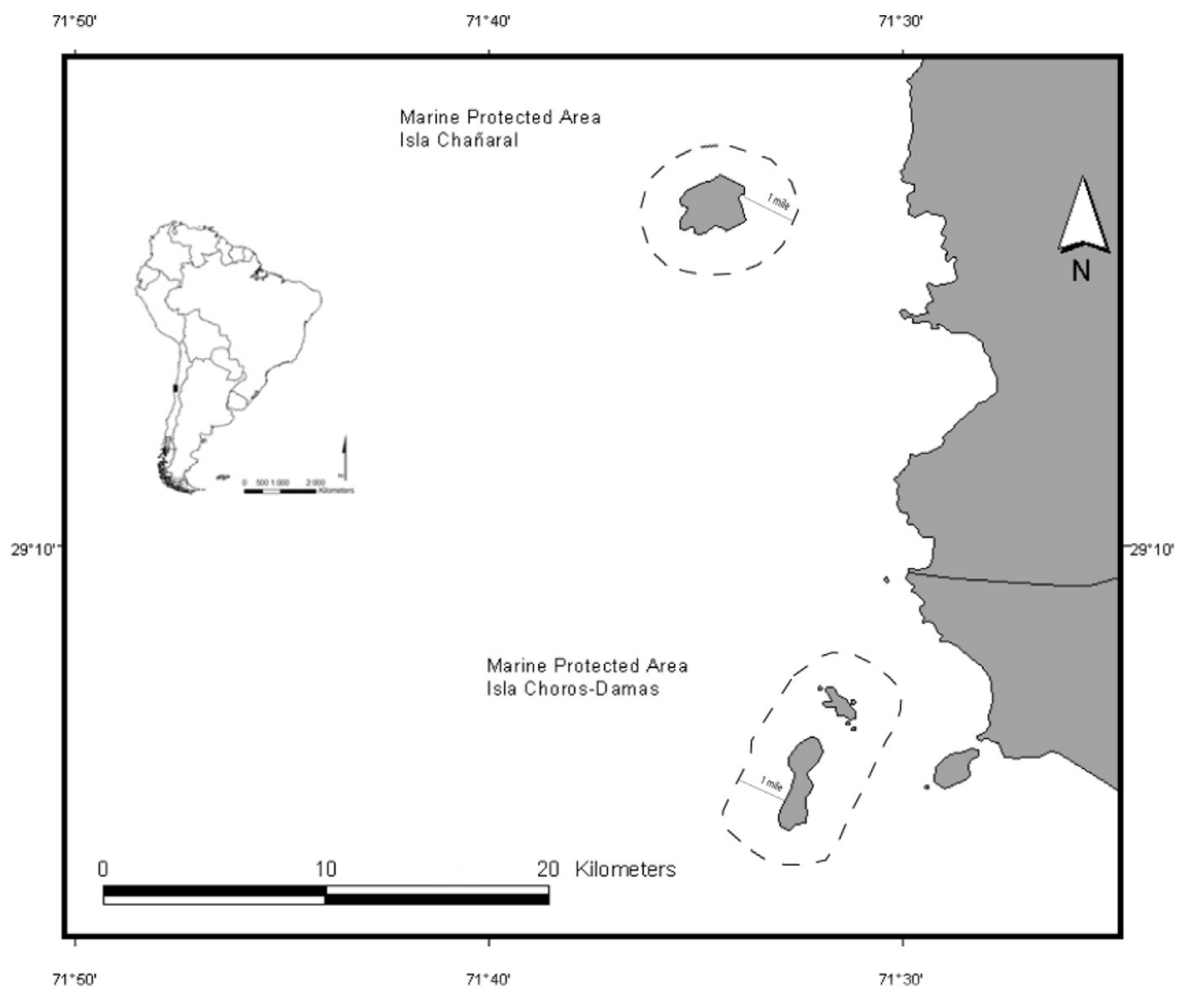

Figure 1. Study area, Marine Protected Areas 'Reserva Marina Isla Chañaral' and 'Reserva Marina Islas Choros-Damas', on the north-central coast of Chile.
South Atlantic Ocean, the Macquarie stock in the southern Pacific Ocean, and Península Valdés stock in Argentina (Lewis et al., 1998; 2006; McMahon et al., 2003; Bester and Hofmeyr, 2005). Although there are no records of breeding colonies along the Chilean coast, opportunistic sightings of the species have been described for the northcentral coast of Chile, Isla Diego Ramírez, Magellanic Region and Isla de Pascua (Sielfeld, 1978; Aguayo et al., 1995; Torres et al., 2000; Lewis et al., 2006). Additionally, historical information indicates the presence of M. leonina on Isla Juan Fernandez (Sielfeld, 1983). Nevertheless, site fidelity has been not mentioned in these studies. This note reports the presence and re-sigthing of southern elephant seals within the Reserva Nacional Pingüino de Humboldt (RNPH), in central Chile.

Monthly boat-surveys have been performed since February 2003 as part of the research project 'Photoidentification of bottlenose dolphin Tursiops truncatus around the RNPH. The study area comprises three islands that belong to the Marine Protected Areas 'Reserva Marina Isla Chañaral' $\left(29^{\circ} 02^{\prime} S\right.$, $71^{\circ} 36^{\prime} \mathrm{W}$ ) and 'Reserva Marina Islas Choros-Damas' (29¹4'S, $\left.71^{\circ} 32^{\prime} \mathrm{W}\right)$ north central Chile (Figure 1). During some of the surveys, the presence of $M$. leonina was recorded based on diagnostic characteristics observed by $8 \times 42$ binoculars. Once the species was identified, its geographic position and photographs were taken. Categorization of each individual was done following Laws (1953).

During the summer months from 2004 to 2007, four sightings of southern elephant seals were recorded. The first two sightings (28 December 2004 and 27 November 2005) were recorded in Isla Chañaral.

\footnotetext{
${ }^{1}$ Eutropia. Centro de Investigación de Aves y Mamíferos Marinos de Chile. 1 Poniente 960, Depto. 1102, Viña del Mar, Chile.

${ }^{2}$ Centro de Investigación y Gestión en Recursos Naturales (CIGREN), Facultad de Ciencias, Universidad de Valparaíso. Gran Bretaña

1111, Playa Ancha, Valparaíso, Chile.

* Corresponding author. Tel.: +56322508346; fax: +56322508072. E-mail address: maritza.sepulveda@eutropia.cl.
} 
These referred to the same individual, which was classified as an immature male. The identification was based on a notorious scar on its back (Figure 2). In 2005, the seal was observed larger and darker than the previous year, and presented clear evidence of molting. Additionally, the scar was less visible than the previous record. The other two sightings (30 January 2006 and 30 January 2007) were registered in Isla Choros. Both individuals were classified as immature males, but they represented different individuals to the male found in Isla Chañaral.

Though Chile does not represent a regular breeding area for southern elephant seals, their presence in this area is not an anomalous record. Recent foraging studies demonstrate that elephant seals show some of the greatest horizontal movements of any mammal, traveling over $5000 \mathrm{~km}$ from their breeding areas
(Hindell and McMahon, 2000; Hindell et al., 2003; Campagna et al., 2007). Similarly, a site preference and long-term fidelity to breeding and molting regions have been demonstrated both in juvenile and adult elephant seals (Hindell and Burton, 1988; McMahon et al., 1999; Lewis et al., 2006). The re-sighted individual for two consecutive years corroborates the hypothesis that elephant seals are able to select sites early in their life (Bradshaw et al., 2004).

However, why do elephant seals select the RNPH during summer months? At least two explanations can be hypothesized. First, the area is an isolated and calm site that allows a seal to rest and molt, as was observed in the re-sighted individual in 2005 . Second, the presence of seals in the study area could be associated with an abundant food resource as characterized by upwelling events during spring and summer (Marín et al., 2003).

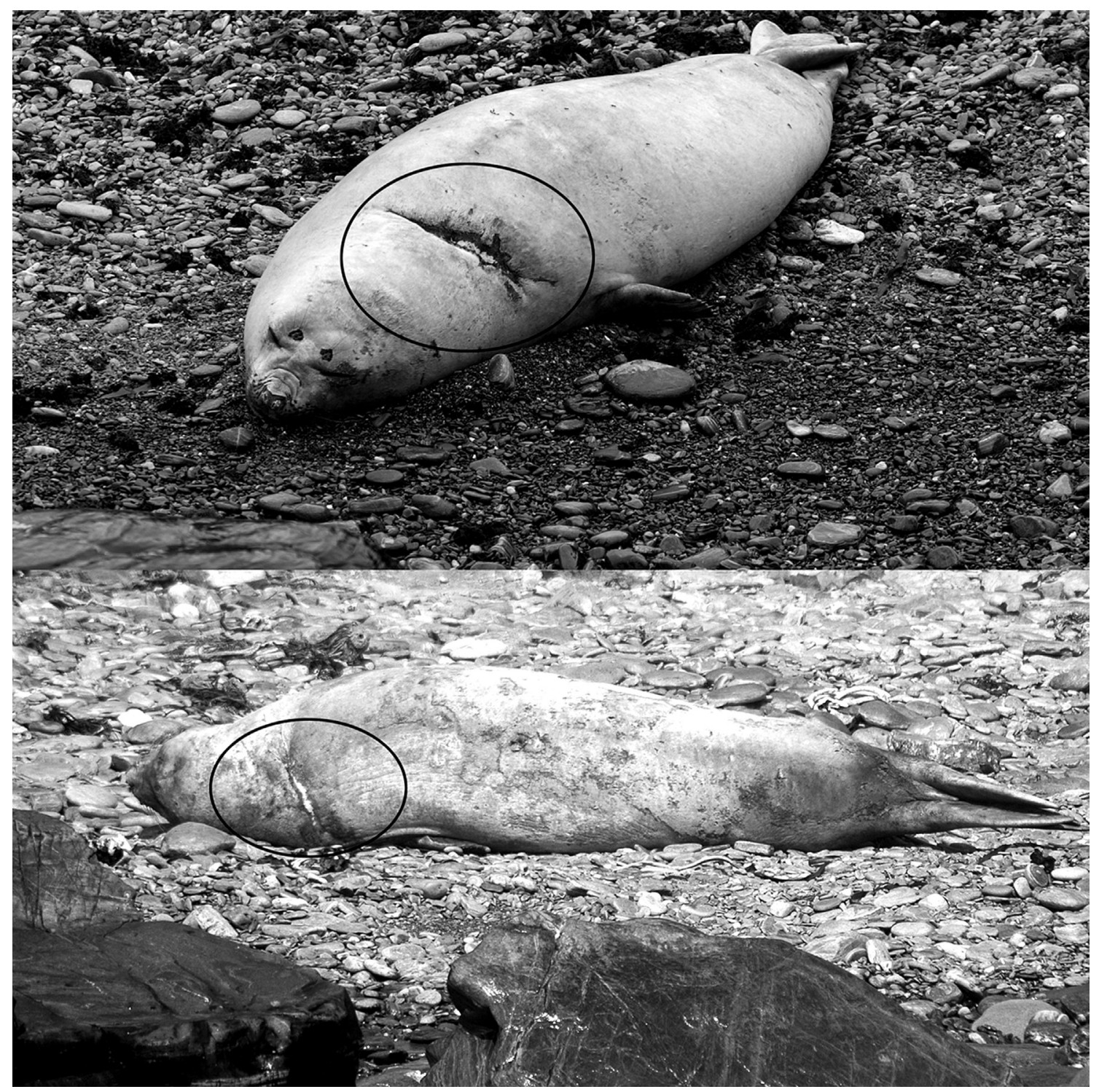

Figure 2. Mirounga leonina re-sighted individual in the Reserva Marina Isla Chañaral; (a) December 2004, and (b) November 2005. 
It is generally believed that top predators such as marine mammals and birds use regions of higher productivity to supply sufficient food for survival and reproductive output (Bradshaw et al., 2002). The upwelling off Coquimbo, Chile $\left(30^{\circ} \mathrm{S}\right)$ in the Humboldt Current ecosystem represents a highly dynamic coastal environment that supports one of the most productive global fisheries (Montecino et al., 1996; Montecino and Quiroz, 2000), and it serves as nutritional sources for a great diversity of marine animals, including marine birds such as Humboldt's penguins (Spheniscus humboldtii), Peruvian diving petrels (Pelecanoides garnotti), marine otters (Lontra felina), South American sea lions (Otaria flavescens), and cetaceans such as bottlenose dolphins (Tursiops truncatus), humpback whales (Megaptera novaeangliae) and fin whales (Balaenoptera physalus) (Capella et al., 1999; Pérez et al., 2006). Additionally, shallow depths located around the study area could be an advantage for seals, which could reduce the energy expenditure while foraging (Campagna et al., 2007).

The presence and residence of elephant seals within the RNPH contributes to the marine ecosystem biodiversity and supports the importance of an integrated conservation of the area. A marine reserve has been recently created around the area in order to conserve and protect the ecologically representative marine environment, ensuring the sustainable use of marine resources (Subsecretaría de Pesca, Decrees no. 150 and 151, 2005). However, an effective management plan is urgently needed to minimize anthropogenic impacts and threats on marine mammals and to protect unique habitats and resident marine communities, which are the ultimate goals of Marine Protected Areas (Boersma and Parrish, 1999). The occurrence and site fidelity of M. leonina within this area allowed for the implementation of systematic scientific research focused on the migratory patterns of the species, as well as the development of a sustainable base for ecotourism.

\section{Acknowledgments}

We thank Patricio Ortiz and Aurelio Aguirre for their experience and support on fieldwork. We also thank Doris Oliva who provided helpful comments on early versions of the manuscript, and to Mirtha Lewis and an anonymous reviewer for their insightful suggestions.

\section{References}

Aguayo, A., Ibañez, P., Rauch, M. and Vallejos, V. (1995) Primer registro del elefante marino del sur, Mirounga leonina, en la Isla de Pascua, Chile. Serie Científica Instituto Antártico Chileno (INACH) 45: 123-129.

Bester, M.N. And Hofmeyr, G.J.G. (2005) Numbers of elephant seals at Prince Edward Island, Southern Ocean. South African Journal of Wildlife Research 35(1): 85-88.
BoERSMA, P. AND PARRISH, J. (1999) Limit abuse: marine protected area, a limited solution. Ecological Economics 31: 287-304.

Bradshaw, C.J.A., Hindell, M.A., Michael, K.J. And Sumner, M.D. (2002) The optimal spatial scale for the analysis of elephant seal foraging as determined by geo-location in relation to sea surface temperatures. ICES Journal of Marine Science 59: 770-781.

Bradshaw, C.J.A., Hindell, M.A., Best, N.J., Phillips, K.L., Wilson, G. AND Nichols, P.D. (2003) You are what you eat: describing the foraging ecology of southern elephant seals (Mirounga leonina) using blubber fatty acids. Proceedings of the Royal Society of London Series B, Biological Sciences 270: 1283-1292.

Bradshaw, C.J.A., Hindell, M.A., Sumner, M.D. and Michael, K.J. (2004) Loyalty pays: potential life history consequences of fidelity to marine foraging regions by southern elephant seals. Animal Behaviour 68: 1349-1360.

Campagna, C., Lewis, M. and Baldi, R. (1993) Breeding biology of southern elephant seals in Patagonia. Marine Mammal Science 9: 34-47.

CAmpagna, C., Rivas, A.L. And Marin, M.R. (2000) Temperature and depth profiles recorded during dives of elephant seals reflect distinct ocean environments. Journal of Marine Systems 24: 299-312.

Campagna, C., Piola, A.R., Marin, M.R., Lewis, M., ZajaczKovski, U. and Fernández, T. (2007) Deep divers in shallow seas: Southern elephant seals on the Patagonian shelf. Deep Sea Research Part I: Oceanographic Research Papers 54(10): 1792-1814.

Capella, J., Vilina, Y. and GibBons, J. (1999) Observación de cetáceos en isla Chañaral y nuevos registros para el área de la Reserva Nacional Pingüino de Humboldt, norte de Chile. Estudios Oceanológicos 18: 57-64.

Hindell, M.A. And Burton, H.R. (1988) Seasonal haul-out patterns of the southern elephant seal (Mirounga leonina. L.) at Macquarie Island. Journal of Mammalogy 69: 81-88.

Hindell, M.A. And McMahon, C.R. (2000) Long distance movement of a southern elephant seal (Mirounga leonina) from Macquarie Island to Peter $1 \varnothing y$. Marine Mammal Science 16: 504-507.

Hindell, M.A., BradshaW, C.J.A., Sumner, M.D., Michael, K.J. AND BurTON, H.R. (2003) Dispersal of female southern elephant seals and their prey consumption during the austral summer: relevance to management and oceanographic zones. Journal of Applied Ecology 40: 703-715.

Laws, R.M. (1953) The elephant seal (Mirounga leonina Linn.). I. Growth and age. Falkland Islands Dependencies Survey. Scientific Report No. 8, London. 66 pp.

Laws, R.M. (1994) History and present status of southern elephant seal populations. Pages 49-65 in Le Boeuf, B.J. AND Laws, R.M. (Eds) Elephant Seals: Population Ecology, Behavior and Physiology. University of California Press, Berkeley, CA, USA.

Lewis, M., Campagna, C., Quintana, F. and Falabella, V. (1998) Estado actual y distribución de la población del elefante marino del sur en la Península de Valdés, Argentina. Mastozoología Neotropical 5(1): 29-40.

Lewis, M., Campagna, C., Marin, M.R. and Fernández, T. (2006) Southern elephant seals north of the Antarctic Polar Front. Antarctic Science 18(2): 213-221. 
Marín, V.H., Delgado, L. and Luna-Jorquera, G. (2003) Schlorophyll squirts at $30^{\circ} \mathrm{S}$ off the Chilean coast (eastern South Pacific): Feature-tracking analysis. Journal of Geophysical Research 108(12): 1-6.

McMahon, C.R., Burton, H.R. And Bester, M.N. (1999) Firstyear survival of southern elephant seals, Mirounga leonina, at sub-Antarctic Macquarie Island. Polar Biology 21: 279-284.

McMahon, C.R., Burton, H.R. And Bester, M.N. (2003) A demographic comparison of two southern elephant seal populations. Journal of Animal Ecology 72: 61-74.

Montecino, V. And Quiroz, D. (2000) Specific primary production and phytoplankton cell size structure in an upwelling area off the coast of Chile $\left(30^{\circ} \mathrm{S}\right)$. Aquatic Science 62: $364-380$

Montecino, V., Pizarro, C. And Quiroz, D. (1996) Dinámica fitoplanctónica en el sistema de surgencia frente a Coquimbo $\left(30^{\circ} \mathrm{S}\right)$ a través de la relación funcional entre fotosíntesis e irradianza (P-I). Gayana Oceanologia 4(2): 139-151.

Pérez, M.J., Thomas, F., Uribe, F., Sepúlveda, M., Flores, M. and Moraga, R. (2006) Fin whale (Balaenoptera physalus) feeding on Euphausia mucronata in nearshore waters off North-Central Chile. Aquatic Mammals 32(1): 109-113.

Sielfeld, W. (1978) Algunas consideraciones sobre fócidos (Pinnipedia) asociados a las costas de Chile. Anales del Instituto de la Patagonia 9: 153-156.

Sielfeld, W. (1983) Mamíferos Marinos de Chile. Ediciones de la Universidad de Chile, Santiago, Chile. 199 pp.

Torres, D., Aguayo-Lobo, A. And Acevedo, J. (2000) Mamíferos Marinos de Chile. II. Carnivora. Serie Científica INACH 50: 25-103. 